\title{
Tubercular mycotic aortic aneurysm presenting with fever of unknown origin
}

\author{
Kökeni bilinmeyen ateşle ortaya çıan tüberküler mikotik aort anevrizması
}

\author{
Ayşegül Beste Öztepe, ${ }^{1}$ Andaç Komaç, ${ }^{1}$ Rıfat Somay, ${ }^{2}$ Şükran Köse, ${ }^{2}$ Harun Akar ${ }^{1}$ \\ ${ }^{1}$ Department of Internal Medicine, Tepecik Training and Research Hospital, İzmir, Turkey \\ ${ }^{2}$ Department of Infectious Diseases, Tepecik Training and Research Hospital, İzmir, Turkey
}

\begin{abstract}
Mycotic aneurysms and infected aneurysms are synonyms. Mycotic aneurysm secondary to tuberculosis is a rare entity. In this article we report a case presenting with fever of unknown origin and abdominal pain and diagnosed with mycotic aortic aneurysm secondary to miliary tuberculosis, paraaortic lymph node involvement which is ultimately referred for surgery after anti-tuberculosis treatment.

Keywords: Miliary tuberculosis; mycotic aortic aneurysm; tubercular mycotic aortic aneurysm.
\end{abstract}

$\ddot{O Z Z}$

Mikotik anevrizmalar ve enfekte anevrizmalar eş anlamlıdır. Tüberküloza sekonder mikotik anevrizma nadir bir durumdur. Bu makalede kökeni bilinmeyen ateş ve karın ağrısı ile başvuran, miliyer tüberküloza sekonder, paraaortik lenf nodu tutulumuna bağlı mikotik aortik anevrizma tanısı konan ve anti-tüberküloz tedavisi sonrası ameliyat için yönlendirilen bir olgu sunuldu.

Anahtar sözcükler: Miliyer tüberküloz; mikotik aortik anevrizma; tüberküler mikotik aortik anevrizma.

Mycotic aneurysm is a term that describes infected aneurysms. William Osler described mycotic aneurysm as synonymous with infected aneurysm. This infection was localized in the arterial wall by means of the embolic occlusion or by vaso-vasorum. ${ }^{[1]}$ These aneurysms may be true or pseudoaneurysms. While the true aneurysm includes all three layers of the arterial wall (intima, media, adventisia), pseudoaneurysm is formed by limiting the blood leaking out of the arterial wall to the tissue. ${ }^{[2]}$ In this article, we would like to discuss the presence of mycotic aortic aneurysm secondary to miliary tuberculosis (MT) and paraaortic lymph node involvement with fever and abdominal pain.

\section{CASE REPORT}

A 55-year-old female patient with no history of known chronic disease was admitted to our clinic with complaints of fever, abdominal and back pain for one month. Despite the use of antibiotics, there was an ongoing history of fever. Physical examination showed a blood pressure of 110/70 mmHg, pulse: 88 beats/min, fever: $38^{\circ} \mathrm{C}$. The rest of the systemic examination was normal and there was no palpable lymphadenopathy. She did not describe traveling around or outside the country, infectious disease, drinking tap water, fresh cheese consumption, livestock, tickbite, suspicious sexual intercourse, recent blood transfusions or operations. The laboratory tests 


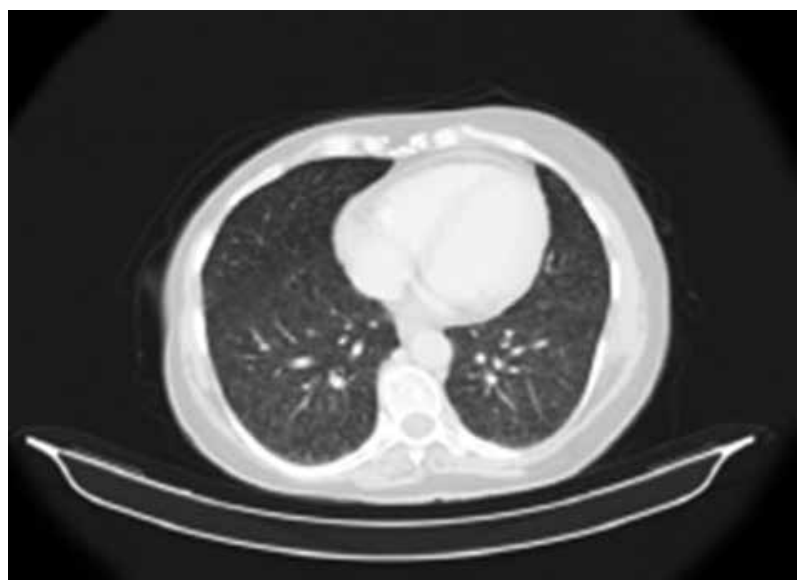

Figure 1. On thoracic tomography, diffuse millimetric nodules in the lungs, enlargement of the right upper lobe bronchus and intrabronchial lesions, paraesophageal and retrocrural necrotic millimetric lymph nodes and minimal pericardial fluid were determined. These findings were evaluated as compatible with miliary tuberculosis

were as follows; WBC: 9,100 uL, Hgb: $10.8 \mathrm{gr} / \mathrm{dL}$, PLT: 328,000 uL, Urea: $28 \mathrm{mg} / \mathrm{dL}$, Creatinine: $1.0 \mathrm{mg} / \mathrm{dL}$, AST: $59 \mathrm{U} / \mathrm{L}$, ALP: $348 \mathrm{U} / \mathrm{L}$, GGT: $262 \mathrm{U} / \mathrm{L}$, LDH: $293 \mathrm{U} / \mathrm{L}$, Total protein: $6 \mathrm{~g} / \mathrm{dL}$, Albumin: $2.7 \mathrm{~g} / \mathrm{dL}$, Globulin: $3.3 \mathrm{~g} / \mathrm{dL}$, Ferritin: $>450 \mathrm{ng} / \mathrm{mL}$, Erythrocyte sedimentation rate: $91 \mathrm{~mm} / \mathrm{h}, \mathrm{CRP}: 20.3 \mathrm{mg} / \mathrm{dL}$, and procalcitonin: $0.36 \mathrm{ng} / \mathrm{mL}$. Viral hepatitis serology and autoimmune hepatitis markers were negative. Anti-HIV was negative. Brucella agglutination, VDRL Venereal Diseases Research Laboratory), ANA (antinuclear antibodies), c-ANCA (Anticytoplasmic-neutrophil cytoplasmic antibodies), perinüklear-ANCA, anti-CCP (Anti cyclic citrullinated eptide) were negative. The patient's serum was tested for the presence of rheumatoid factor $(\mathrm{RF})$ and the results were $<20$. Urine

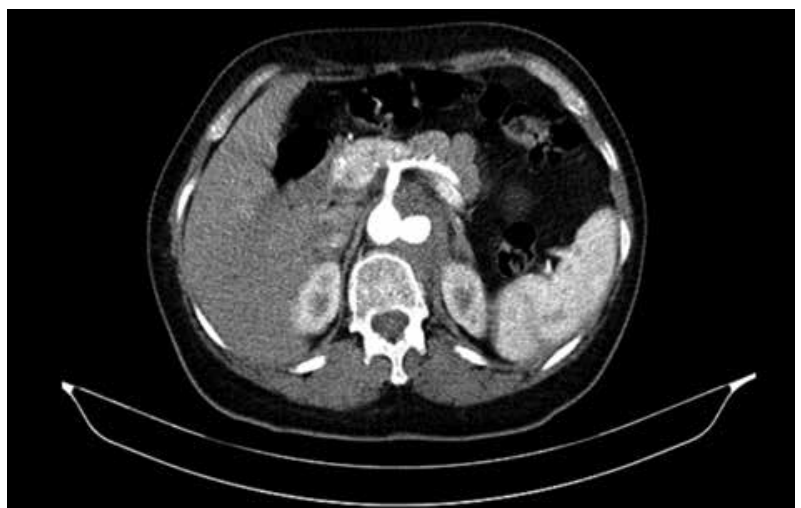

Figure 2. The fat plane between the lesion and the aorta was lost and there was contrast filling in the lesion. This appearance was evaluated as tuberculousis necrotic lymph node and aneurysm formation.

analysis was normal. Salmonella typhi $\mathrm{O}$ and $\mathrm{T}$ agglutinations were found to be $1 / 40$ positive but not significant. Blood and urine cultures were taken due to persistent fever. Blood and urine cultures were negative. Echocardiography showed no vegetation. Computed tomography of thorax and abdomen was obtained. On thoracic tomography, diffuse millimetric nodules in the lungs, enlargement of the right upper lobe bronchus and intrabronchial lesions, paraesophageal and retrocrural necrotic millimetric lymph nodes and minimal pericardial fluid were determined. These findings were evaluated as compatible with miliary tuberculosis (Figure 1). A necrotic paraaortic lesion with anterior posterior dimension of $5.5 \mathrm{~cm}$, mediolateral dimension of $3.5 \mathrm{~cm}$ and superior inferior dimension of $6 \mathrm{~cm}$ was observed on the left retrocrural level. The fat plane between the lesion and the aorta was lost and there was contrast filling in the lesion. This appearance was evaluated as tuberculousis (TB) necrotic lymph
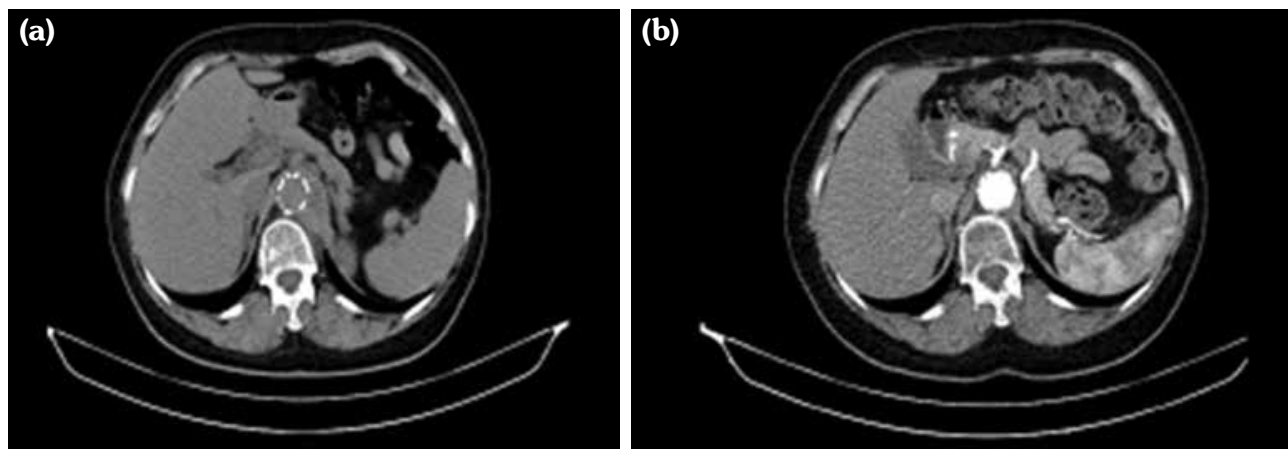

Figure 3. Post-TEVAR control computed tomography angiography. 
node and aneurysm formation (Figure 2). Purified protein derivative testing was positive with $20 \mathrm{~mm}$ of induration. Biopsy due to aneurysm was found to be risky. Biopsy was not done. Treatment started with rifampicin $10 \mathrm{mg} / \mathrm{kg}$, ethambutol $20 \mathrm{mg} / \mathrm{kg}$, pyrazinamide $25 \mathrm{mg} / \mathrm{kg}$ and isoniazid $5 \mathrm{mg} / \mathrm{kg}$. After the antituberculosis treatment started, the patient's fever was under control. The patient planned to have aortic endovascularcovered graft stent (TEVAR), but cardiovascular surgeon did not approve of TEVAR for truncus coeliacus occlusion. The patient was referred to surgery for an aortic aneurysm operation. The latest computed tomography (CT) angiography image taken at the controls performed in our hospital is shown in Figure 3.

\section{DISCUSSION}

Tuberculosis is a granulomatous disease caused by Mycobacterium TB, which currently remains an important public health threat globally, especially in endemic countries and in individuals who have immunodeficiency. ${ }^{[3,4]}$ Pulmonary TB is the most common presentation, but it can disseminate into other organs and causes extrapulmonary TB. ${ }^{[5,6]}$ Migration of Mycobacterium TB from the initial site of infection to other organs may cause fatal diseases such as miliary TB. ${ }^{[5]}$ Miliary TB is an infection of disseminated hematogenous disease. Immunocompromised individuals are generally more prone to miliary TB. ${ }^{[7]}$ Especially high blood flow organs (lung, liver, spleen, bone marrow, eyes, kidneys, adrenal glands) can be affected at different rates. As seen in our patient, fever may occur with nonspecific symptoms such as weight loss, sweating, fatigue or symptoms may occur according to the affected area. It is important to demonstrate acid-resistant bacilli in the specimen taken from sputum, bronchoalveolar lavage or from the affected organs for diagnosis. Our patient could not give a sputum sample. Biopsy from the aneurysm site is considered risky for aneurysm rupture. For these reasons, no samples were taken. Based on the clinical picture and imaging modalities, anti-tuberculosis treatment was initiated and clinical improvement was achieved.

Mycotic aneurysms and infected aneurysms are synonyms. ${ }^{[8]}$ Despite their rare occurrence, they require close follow-up because they can cause high mortality and morbidity such as bleeding and sepsis. ${ }^{[9]}$ Arterial injury, premature infections (such as endocarditis, pneumonia, dental infection, cholecystitis), impaired immunity, atherosclerosis, current aneurysm can be listed as mycotic aneurysm risk factors. ${ }^{\left[{ }^{[]}\right.}$In addition to history and physical examination, laboratory tests and imaging modalities are important for mycotic aneurysm. Seventy percent of patients with mycotic aneurysms were immunosuppressed. ${ }^{[10]}$ Moneta et al. ${ }^{[11]}$ reported the clinical characteristics of 17 infected aortic aneurysms treated by a single group. All of the patients had abdominal/back pain, $88 \%$ had fever and $71 \%$ had leucocytosis. ${ }^{[11]}$ In this study, the two most common organisms were Staphylococcus aureus (29\%) and Salmonella organisms (24\%).[11] Diagnosis of mycotic aneurysm can be made by producing a microorganism in the blood culture, and especially by CT angiography, to find a suitable appearance for infected aneurysm. Among the causes of infected aneurysms, Treponema pallidum and Mycobacterium TB are rarely encountered. While syphilis was seen more often in the past, nowadays the frequency has decreased. Mycotic aneurysms due to TB often arise as a consequence of aortic wall erosion caused by infected periaortic lymph nodes. Infected aortic aneurysms can lead to uncontrolled sepsis and/or aortic rupture. ${ }^{[12,13]}$ A high index of suspicion is essential to make the diagnosis of an infected aortic aneurysms. Lee et al. ${ }^{[14]}$ suggested that the CT features of mycotic aneurysm of aorta included (i) hazy aortic wall with rupture; (ii) gas-forming inflammation around the aneurysm; (iii) retroperitoneal paraaortic fluid collection and vertebral erosion; and (iv) thrombus formation within a false lumen after aneurysmal rupture. Lee et al. ${ }^{[14]}$ also suggested that $\mathrm{CT}$ is the major diagnostic modality to use for Salmonella-related mycotic aneurysm. Brossier et al. ${ }^{[15]}$ identified 26 patients with infected aneurysms and the causative organisms identified as Campylobacter fetus, Streptococcus pneumoniae, Listeria, Salmonella, Mycobacterium TB ( $\mathrm{n}=2)$, Staphylococcus aureus. Brossier et al. ${ }^{[15]}$ suggested that the bacteriological spectrum of infected aneurysms was wider than previously reported possibly due to the availability of new diagnostic tests and increased prevalence of immunosuppression. Immune suppression was a feature in $38.4 \%$ of patients. Costiniuk et al. ${ }^{[16]}$ reported a case with 
a ruptured abdominal aortic aneurysm who had previously received intravesical BCG (Bacillus Calmette-Guerin) therapy for bladder carcinoma. Canaud et al. ${ }^{[17]}$ reported a single-center experience of three patients treated with a combination of surgical aortic replacement and prolonged antituberculosis therapy. Long et al. ${ }^{[18]}$ found 39 cases of tuberculous mycotic aneurysms in the aorta between 1945 and 1999 in their literature review. They evaluated 41 cases with tuberculous mycotic aneurysms with two cases of their own. Long et al. ${ }^{[18]}$ suggested that tuberculous mycotic aneurysm of the aorta appeared to result from erosion of the aortic wall by a contiguous focus; direct seeding of the aortic intima or via the vasa vasorum and most of the aneurysms were saccular and false. Long et al. ${ }^{[18]}$ suggested that in case of active tuberculosis, and especially miliary TB, tuberculous mycotic aneurysm of the aorta should be suspected in the presence of persistent pain, major bleeding, and a palpable or radiographically visible para-aortic mass, especially if it is expanding or pulsatile.

There are no guidelines for the management of tuberculous mycotic aneurysms, and treatment strategies are based on clinical experiences. The treatment is based on ensuring adequate blood flow by reconstruction of the vessel after infection control. Early diagnosis and treatment has critical prescription, as the tendency to rupture is high. In our patient, infection was controlled with tuberculosis treatment and the case was referred for surgery. Infected aortic aneurysms are rare and difficult to treat. Soravia-Dunand et al..12] suggested that the use of bactericidal antibiotics, together with early surgical intervention and long-term suppressive antibiotic therapy, has led to improved survival. Mycotic aneurysm secondary to tuberculous infection of the aorta is a rare and life-threatening disease. Conventional treatment of mycotic aortic aneurysms usually includes aortic ligation, aneurysmal excision, and extra-anatomic bypass grafting. ${ }^{[9]}$ It is suggested that mycotic aortic aneurysms can be successfully treated if diagnosis and treatment are timely and in multidisciplinary collaboration.

\section{Declaration of conflicting interests}

The authors declared no conflicts of interest with respect to the authorship and/or publication of this article.

\section{Funding}

The authors received no financial support for the research and/or authorship of this article.

\section{REFERENCES}

1. Osler W. The Gulstonian Lectures, on Malignant Endocarditis. Br Med J 1885;1:467-70.

2. Anthony S, Charles MM, Steven FH, Lois S, Julius HJ, Jonathan LH. Femoral pseudoaneurysm following nonpenetrating trauma in a patient with aortic insufficiency. The American Journal of Medicine 1985;78:719-20.

3. Paez Soria E, Magnano P, Schlaen A, Luvini P, Arevalo Calderon G, Martinez Cartier M, et al. Tuberculous Subretinal Abscess in a Non-HIV Patient with Miliary Tuberculosis. Case Rep Ophthalmol 2016;7:292-300.

4. Nergizoglu G, Duman N, Ertürk S, Keven K, Ateş K, Akar $\mathrm{H}$, et al. Tuberculosis of the skull in a patient on maintenance haemodialysis. Nephrol Dial Transplant 1999;14:2019-21.

5. Yang D, Kong Y. The bacterial and host factors associated with extrapulmonary dissemination of Mycobacterium tuberculosis. Front Biol (Beijing) 2015;10:252-61.

6. Taskıran E, Yllırım M, Soyaltın UE, Gulle S, Dereli MS, Akar H. Tuberculosis infection with hepatic involvement mimicking liver metastasis in an elderly patient. Europ Geriat Med 2016;7:369-71.

7. Al-Mendalawi MD. Miliary tuberculosis disease complicated by Pott's abscess in an infant: Seven-year follow-up. Lung India 2015;32:676-7.

8. Qureshi T, Hawrych AB, Hopkins NF. Mycotic aneurysm after percutaneous transluminal femoral artery angioplasty. J R Soc Med 1999;92:255-6.

9. Johansen K, Devin J. Mycotic aortic aneurysms. A reappraisal. Arch Surg 1983;118:583-8.

10. Oderich GS, Panneton JM, Bower TC, Cherry KJ Jr, Rowland CM, Noel AA, et al. Infected aortic aneurysms: aggressive presentation, complicated early outcome, but durable results. J Vasc Surg 2001;34:900-8.

11. Moneta GL, Taylor LM Jr, Yeager RA, Edwards $\mathrm{JM}$, Nicoloff AD, McConnell DB, et al. Surgical treatment of infected aortic aneurysm. Am J Surg 1998;175:396-9.

12. Soravia-Dunand VA, Loo VG, Salit IE. Aortitis due to Salmonella: report of 10 cases and comprehensive review of the literature. Clin Infect Dis 1999;29:862-8.

13. Gomes MN, Choyke PL. Infected aortic aneurysms: CT diagnosis. J Cardiovasc Surg (Torino) 1992;33:684-9.

14. Lee MH, Chan P, Chiou HJ, Cheung WK. Diagnostic imaging of Salmonella-related mycotic aneurysm of aorta by CT. Clin Imaging 1996;20:26-30. 
15. Brossier J, Lesprit P, Marzelle J, Allaire E, Becquemin JP, Desgranges P. New bacteriological patterns in primary infected aorto-iliac aneurysms: a single-centre experience. Eur J Vasc Endovasc Surg 2010;40:582-8.

16. Costiniuk CT, Sharapov AA, Rose GW, Veinot JP, Desjardins M, Brandys TM, et al. Mycobacterium bovis abdominal aortic and femoral artery aneurysms following intravesical bacillus Calmette-Guérin therapy for bladder cancer. Cardiovasc Pathol 2010;19:29-32.

17. Canaud L, Marzelle J, Bassinet L, Carrié AS, Desgranges P, Becquemin JP. Tuberculous aneurysms of the abdominal aorta. $J$ Vasc Surg 2008;48:1012-6.

18. Long R, Guzman R, Greenberg H, Safneck J, Hershfield E. Tuberculous mycotic aneurysm of the aorta: review of published medical and surgical experience. Chest 1999;115:522-31. 